American Journal of Agricultural and Biological Sciences 3 (3): 623-626, 2008

ISSN 1557-4989

(C) 2008 Science Publications

\title{
Brucellosis in Camels (Camelus dromedorius) in the south province of Jordan
}

\author{
Hawari Azmi Dawood \\ Department of Nutrition and Food Processing, Al-Balqa Applied University, \\ Faculty of Agricultural Technology, Al-Salt 19117, Jordan
}

\begin{abstract}
A study of the prevalence of camel brucellosis has been carried out in the south province of Jordan during the years 2006 and 2007. Six hundred forty camel sera from 44 herds were randomly collected and analyzed. Rose Bengal plate test was used to screen all serum samples. The positive samples were subjected to confirmation by complement fixation test. The true prevalence of Brucella seropositive was $15.8 \%$. Brucella melitensis biotype 3 was isolated from 2 aborted fetuses and from 2 milk samples. $64.8 \%$ of the positive camels were adult $>$ than 4 years old and the remaining $35.2 \%$ were young ranging from 6 months to 4 years old. Recommendations for brucellosis control were given.
\end{abstract}

Keywords: Camels, brucellosis, serology, prevalence, Jordan

\section{INTRODUCTION}

Brucellosis, a disease caused by various species of the genus Brucella, has the most wide-spread zoonosis in the world ${ }^{[1]}$. Cross-transmission of brucellosis can occur between cattle, sheep, goats, camels and other species. Brucellosis are still endemic in countries of the Mediterranean basin, the middle east and central Asia. Human infection due to Brucella from camels is known to occur mostly through the consumption of unheated milk $^{[2,3,4]}$. It is prevalent in the countries surrounding $\operatorname{Jordan}^{[5,6,7]}$. In Jordan there was some evidence that brucellosis does occur in different animals and human $^{[8,9,10]}$. Camels are frequently infected with Brucella organisms, especially when they are in contact with infected large and small ruminants ${ }^{[2,11]}$. Serological evidence for Brucella infection in camels has been reported from Asia and Africa ${ }^{[11,12,13,14]}$. The relation between Brucella infection and abortion in camels has been recorded ${ }^{[10,15,16]}$. Both Brucella abortus and Brucella melitenis have been isolated from fetuses, genital discharges, urine and milk ${ }^{[2]}$. In Jordan, serology, bacteriology and epidemiology of brucellosis in sheep and goats has been studied extensively and the prevalence was found to vary from $14.3-27.7 \%^{[8,9]}$. The study of brucellosis in camels in Jordan was not clear. The only study was conducted by Al-Majali et $a l^{[10]}$. He reported that the true prevalence of Brucella seropositive in camels was $12.1 \%$ and the Brucella melitensts biotype 3 was isolated from aborted camel fetuses.

The complexity of disease epidemiology and the lack of exact camel population concerning detailed demographic data are among the major factors that have constrained disease control in Jordan. However unofficial records suggest a total camel population between 14.000 and 16.000 head. Nearly all camels are by nomads under traditional methods of husbandry.

The aim of the present study was to investigate the seroprevalence of brucellosis in the south province of Jordan and typing of isolated Brucella spp.

\section{MATERIALS AND METHODS}

This study was conducted during the years 2006 and 2007 in the south province of Jordan.

Animals: The present study involved 44 herds of 640 heads of camels (Camelus dromedaries). The number of camel heads per herd range between 12-40. With the aid of a questionnaire, information of each camel sampled was obtained including its location, herd size, sex, age, health status, history of abortion, wheather reared individually, with other species or in a camel herd.

Sample collecting: In this study only camels older than 6 months were included. Blood samples were collected from 640 camels of both sexes ranging in age from six months to 12 years. The blood was allowed to clot and the sera were separated by centrifugation and stored at $20^{\circ} \mathrm{C}$ until testing.

Serological test: All sera were screened for antibodies against Brucella by the Rose Bengal plate-agglutination test RBPT. All positive serum samples were further 
tested using complement fixation test CFT as described by Alton et al. ${ }^{[17]}$. Both tests were manufactured by (Jovac, Amman, Jordan). Serum sample with an antibody titer equal or more than 1:4 was classified as a (CFT) positive. Camels with both positive RBPT and CFT results considered Brucella seropositive camels. According to the manufacturer, the sensitivity and specificity of RBPT are 89 and $97 \%$, respectively. CFT has a sensitivity of $88.1 \%$ and a specificity of $100 \%{ }^{[18]}$.

Bacteriological examination: Twenty six milk samples were collected with sterile universal bottles from she-camels in different location. In the field fetal stomach contents and the vaginal swabs were used to prepare slide smears, stained by the modified ZiehlNeelsen stain and examined microscopically for Brucella-like organisms. In addition to that fetal stomach contents and swabs of liver, spleen, lungs, from aborted fetuses were obtained and cultured on Brucella agar selective media (oxoid). The inoculated plates were incubated at $37^{\circ} \mathrm{C}$ in presence of $10 \% \mathrm{CO}_{2}$ for up to 2 weeks. Initially Brucella were identified by colony mormphology, Gram-stain and modified ZielNeelsen stain. In all samples suspected colonies were identified and typed as reported by Alton et al. ${ }^{[17]}$. Briefly the colonies that appeared (after 3-4 days of incubation) pinpoint, smooth, translucent, glistening and the bacterial cells that appeared as Gram-negative coccobacilli and showed red color by modified ZielNeelsen stain were subjected to confirmatory test, identified and typed as reported by Alton et al. ${ }^{[17]}$.

Statistical analysis: The Brucella-seroprevalence was estimated by adjusting the apparent prevalence to the sensitivities and specificities of the two serological tests (in series) using the following formula:

$$
\mathrm{TP}=\frac{\mathrm{Ap}-\left(1-\mathrm{Sp}_{1}\right)\left(1-\mathrm{Sp}_{2}\right)}{\mathrm{Se}_{1} \mathrm{Se}_{2}-\left(1-\mathrm{Sp}_{1}\right)\left(1-\mathrm{Sp}_{2}\right)}
$$

Where TP is the true prevalence; AP is the apparent prevalence, $\mathrm{Sp}_{1}$ and $\mathrm{Sp}_{2}$ are $\mathrm{RBPT}$ and CFT tests specificities, respectively; $\mathrm{Se}_{1}$ and $\mathrm{Se}_{2}$ are RBPT and CFT sensitivities, respectively ${ }^{[19]}$.

\section{RESULTS AND DISCUSSION}

Out of the 640 camels sera tested, $91(14.2 \%)$ were positive by RBPT (Table1). When tested by CFT, 79 $(12.3 \%)$ out of the 91 RBPT positive sera were positive by CFT. Therefore, the true seroprevalence of camel brucellosis in south province of Jordan as adjusted to the RBPT and CFT sensitivities and specificities is $15.8 \%$.

Results of serological diagnosis of brucellosis in camels at different locations are summarized in (Table 1). Most positive cases (17\%) were from $\mathrm{Al}$ Mudawwara location near the border of Saudi Arabia (Fig. 1). In general (Table 1) shows 147 male camels and 493 female she-camel were serologically tested. 11 $(7.5 \%)$ and $68(13.8 \%)$ were found positive respectively for the disease. The distribution of infected camels among different age groups is shown in (Table 2). The same table shows that $64.8 \%$ of the positive camels were adult ( $>$ than 4 years old) and the remaining $35.2 \%$ were young, ranging from 6 month to 4 years old.

From 26 milk samples, two isolates $7.7 \%$ were identified as Brucella micro-organism. In the field smears from 2 fetal stomach contents similarly showed partially acid-fast organism. The smears from the vaginal swabs of the two aborted she-camels was also positive by the modified Ziehl- Neelsen stain.

Table 1: Results of serological diagnosis of brucellosis by RBTP and confirmed by CFT in camels in different loations in the South province of

\begin{tabular}{|c|c|c|c|c|c|c|c|c|c|c|c|c|}
\hline \multirow{2}{*}{ Location } & \multicolumn{3}{|c|}{ Camels examined } & \multirow{2}{*}{\multicolumn{3}{|c|}{ Males }} & \multirow{2}{*}{\multicolumn{3}{|c|}{ Females }} & \multirow{2}{*}{\multicolumn{3}{|c|}{ Aborted females }} \\
\hline & $\begin{array}{l}\text { Camels ex } \\
\text { Total No. }\end{array}$ & $\begin{array}{l}\text { aminec } \\
\text { Pos. }\end{array}$ & $\%$ & & & & & & & & & \\
\hline Aqaba & 34 & 3 & 8.8 & 6 & 1 & 16.7 & 28 & 3 & 10.7 & 2 & 1 & 50 \\
\hline Ram & 70 & 4 & 5.7 & 12 & 1 & 8.3 & 58 & 3 & 5.2 & 4 & 1 & 25 \\
\hline Al Jafr & 50 & 4 & 8 & 18 & 2 & 11.1 & 32 & 2 & 6.2 & N.I & - & - \\
\hline Ash Shawbak & 30 & 1 & 3.3 & - & - & - & 30 & 2 & 6.7 & N.I & - & - \\
\hline Ma'an & 80 & 6 & 7.5 & 24 & 1 & 4.2 & 56 & 5 & 8.9 & 7 & 2 & - \\
\hline Al-Batra & 30 & 2 & 6.7 & 2 & - & - & 28 & 2 & 7.1 & N.I & - & - \\
\hline Al Mudawwara & 346 & 59 & 17 & 85 & 6 & 7 & 261 & 51 & 19.5 & 17 & 9 & 52.9 \\
\hline Total & 640 & 79 & 12.3 & 147 & 11 & 7.5 & 493 & 68 & 13.8 & 30 & 13 & 43.3 \\
\hline
\end{tabular}

No. $=$ Number of animals positive for brucellosis, NI. = No Information .

Table 2: Distribution of positive results in camels among different age groups

\begin{tabular}{llllllll}
\hline & $6-12$ months & $1-2$ years & $2-3$ years & $3-4$ years & $4-5$ years & $5-6$ years & Over 6 years \\
\hline No. of examined animals & 75 & 78 & 62 & 75 & 76 & 85 & 189 \\
No. of positive $(\%)$ & $7(9.3 \%)$ & $8(10.3 \%)$ & $7(11.3 \%)$ & $8(10.7 \%)$ & $10(13.2 \%)$ & $14(16.5 \%)$ & $25(13.2 \%)$ \\
\hline
\end{tabular}




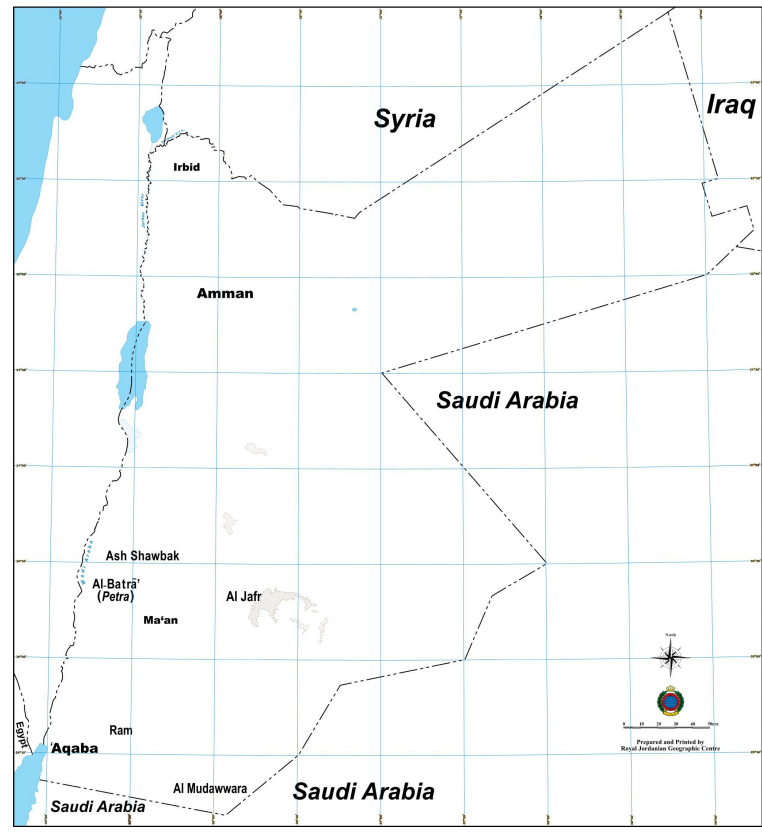

Fig. 1: Locations of sample collection from camels for Seroprevalence of camel brucellosis in the south province of Jordan

Brucella was isolated from the two aborted fetuses. All the isolates from milk and fetuses were characterized as Brucella melitensis biotype3.

Zoonosis continue to present an important health hazard in most parts of the world, particularly in developing countries. Infection may develop in people who are frequently is contact with camel herds, or who drink camel milk and its products ${ }^{[20]}$. Camels are not known to be primary hosts for any of Brucella organisms, but they are susceptible to both Brucella melitensis and Brucella abortus ${ }^{[21]}$.Infection rate in camels depends upon the infection rate in primary hosts animals in contact with them. This may further suggest the role of small ruminants in the occurrence of camel brucellosis.

In Jordan, Brucella melitensis were isolated before in several camels ${ }^{[10]}$. In this study, Brucella melitensis biotype 3 was isolated from two milk samples and from two aborted camel fetuses. Brucella melitensis biotype 3 has been identified before as the main Brucella spp. isolated from small ruminants. These results are in agreement with those of the previous studies ${ }^{[8,9,10]}$.

The buffered Brucella agglutination test such as (RBPT) are known to have high analytical sensitivity ${ }^{[17]}$. Complement fixation test has slightly lower diagnostic sensitivity than that of the buffered agglutination tests, but its specificity is the highest of any of the other convential tests ${ }^{[6]}$. Due to this fact, CFT has been recognized as a confirmatory serological test for brucellosis.

In this study the true seroprevalence of brucellosis in camels in south province of Jordan was found to be $14 \%$. This prevalence was higher than that reported by Al-Majali et al. ${ }^{[10]}$. The high prevalence of brucellosis in south province of Jordan in small ruminants ${ }^{[9]}$ and lack of adequate sheep and goats Brucella control program including vaccination may contribute to this high prevalence of camel brucellosis in this region. In addition to that the high uncontrolled animal movements through the borders could explain the main factor of this high prevalence where camles reared with small ruminant animals. Prevalence of Brucella antibodies in all age groups in camels showed that brucellosis infection started early in life probably through sucking and persisted into adulthood as shown in (Table 2).

In conclusion there are some facts must be taken in consideration in controlling this disease:

- Brucellosis in camels seems to display less clinical sings than in other ruminant animals, so the disease should be controlled by vaccination in camels and primary hosts

- Due to the uncontrolled movements of different animals (camels, sheep and goats) through the borders between Jordan and surrounding countries, it is recommended to vaccinate the animals in Jordan at regular intervals specially along the borders regions. Adequate Brucella control programs in small ruminants may contribute to the reduction in the prevalence of this disease in camels

\section{REFERENCES}

1. Mustafa, M. and P. Nicoletti, 1993. Proceeding of the Workshop on Guidelines for a Regional Brucellosis Control Program for the Middle East. Feb. 14-17, Amman, Jordan. FAO, WHO and OIE. Doi: 10.1016/S0167-5877(03)00127-2

2. FAO/WHO, 1986. Expert committee on brucellosis, Sixth Report. WHO Technical Report series, No. 740. WHO, Geneva.

3. Kiel. F.W. and M.Y. Khan, 1987. Analysis of 506 consecutive positive serological tests for brucellosis in Saudi Arabia. J. Clin. Microbiol., 25: 1384-1387. http://jcm.asm.org/cgi/content/ abstract/25/8/1384

4. Madkour, M.M. 1989. Brucellosis. Butterworths, London, pp: 294. 
5. Radwan, A.I., S.I. Bekairi, A.A Mukayel, A.M. AlBokmy, P.V.S. Prasad, F.N. Azar and E.R. Coloyan. 1995. Control of Brucella melitensis infection in a large camel herd in Saudi Arabia using antibiotherapy and vaccination with Rev. 1 vaccine. Rev. Sci. Tech. Off. Int. Epiz., 14: 719-732. http://www.ncbi.nlm.nih.gov/pubmed /8593404

6. Abbas, B. and H. Agab, 2002. A review of camel brucellosis. Preventive Vet. Med. 55: 47-56. Doi: 10.1016/S0167-5877(02)00055-7.

7. Hegazy, A.A., A. El Dughaym, M. Alaknah, F.M.T. Housawi and M.E. Hatem 2004. Studies on mastitis in Female Camel with Special Reference to Brueellosis. J. Camel. Sci., 1: 96-102. http://www.acsad.org/old1_old/cnl_mar/journal/jcs _mar2004_96.pdf

8. Al -Talafhah, A..H., S.Q. Lafi and Y. Al-Tarazi, 2003. Epidemiology of ovine brucellosis in Awassi sheep in Northern Jordan. Preventive Vet. Med., 60: 297-306. doi: 10.1016/S0167-5877(03)001272.

9. Al-Majali, A.M., 2005. Seroepidemiology of caprine brucellosis in Jordan. Small Ruminant Res., 58: 13-18. http://www.cababstractsplus. org/google/abstract.asp?AcNo=20053064351

10. Al-Majali, A.M., K.M. Al-Qudah, Y.H. Al-Tarazi and O.F. Al-Rawashdeh. 2008. Risk factors associated with camel brucellosis in Jordan. Trop. Anim. Health Prod., 40: 193-200. http://www.ncbi.nlm.nih.gov/pubmed/18484121

11. Radwan, A.I., S.J. Bekairi and P.V.S. Prasad, 1992. Serological and bacteriological study of brucellosis in camels in central Saudi Arabia. Rev. Sci. Tech. OIE, 11: 837-844. http://www.ncbi.nlm.nih. gov/pubmed/1472730

12. Okoh. A.E.J., 1979. A survey of brucellosis in camels in Kano, Nigeria. Trop. Anim. Hlth. Prod., 11: 213-214. DOI : 10.1007/BF02237805 s.

13. Hashim, N.H., G.A. Galil, M.A., Hulaibi and E.M. Al-Saleem, 1987. The incidence of brucellesis and species of Brucella organisms isolated from animals in Al-Hassa. Wld. Anim. Rev., 61: 32-35. http://www.fao.org/agris/search/display.do?f=./198 8/v1403/XF876852788.xml;XF876852788
14. Musa, M.T and T.A. shigidi 2001. Brucellosis in camels in intensive Animal breeding areas of sudan. Implication in abortion and early-life infections. Revue Elev. Med. Vet. Pays Trop, 54: 11-15. http://remvt.cirad.fr/cd/derniers_num /2001/EMVT01_011_015.pdf

15. Higgins, A., 1986. The Camel in Heath and Disese, (Bailliere Tindall, London).

16. Agab, H. and B. Abbas. 1999. Epidemiological studies on camel diseases in eastern Sudan, Wld. Anim. Rev. 92: 42-51. http://www.fao.org/docrep /x1700t/x1700t06.htm

17. Alton, G.G., L. M.Jones, R.D. Angus and J.M. Verger, 1988 Techniques for Brucellosis Laboratory, (INRA Paris).

18. Blasco, J.M., 2006. Existing and future vaccines against brucellosis in small ruminants. Small Rumiant Res., 62: 33-37. Doi: 10.1016/j.smallrumres.2005.07.034.

19. Noordhuizen, J.P., K. Fronkena, C. van der Hoofd and E. Graat 1997. Application of Quntitative Mehthods in Veterinary Epidemiology, (Wageninegen Pers, The Nethrlands). DOI:10.1023/B:TROP.0000009979.16065.5d

20. Nicolleti, P., 1989. Relationship Between Animal and Human Diseases. In: Brucellosis Clinical Laboratory Aspects, Young E.I. and M.J. Corbel (Eds.), Boca Raton, FL., U.S.A. CRC Press, pp: 41-45.

21. Agab, H., B. Abbas, H. El-Jakack and I.E. Mamon, 1994. Firist report on the isolation of Brucella abortus biovar 3 from camel (camelus dromedaries) in Sudan. Revue. Elev. Med. Vet. Pays. Trop., 47: 361-363. http://journals.elsevierhealth.com/periodicals/ymai/ medline/record/MDLN.7770659 